\title{
PENGARUH LINGKUNGAN TERHADAP BENTUK RUMAH PADA PERMUKIMAN TEPIAN SUGAI KOTA BANJARMASIN
}

\author{
Amar Rizqi Afdholy ${ }^{1}$, Lisa Dwi Wulandari ${ }^{2}$, Sri Utami ${ }^{3}$ \\ ${ }^{1}$ Program Magister Arsitektur Lingkungan Binaan, Fakultas Teknik, Universitas Brawijaya, Malang. \\ ${ }^{2,3}$ Staf Pengajar, Jurusan Arsitektur, Fakultas Teknik, Universitas Brawijaya, Malang. \\ amayrizqi30@gmail.com
}

\begin{abstract}
ABSTRAK. Kota Banjarmasin merupakan kota yang dipengaruhi oleh lingkungan sungai. Keberadaan sungai berperan terhadap pembentukan karakteristik identitas Kota Banjarmasin yang dapat dilihat dari permukiman tepian sungainya. Salah satu permukiman tepian sungai yang masih memiliki unsur kelokalan dan kebudayaan sungai yang kuat, yaitu pada permukiman tepian Delta Pulau Bromo. Lingkungan sungai sangat berpengaruh terhadap kehidupan dan aktivitas masyarakat pada permukiman ini. Aktivitas masyarakat yang banyak dilakukan di sungai membuat masyarakat cenderung membangun hunian atau tempat tinggalnya di tepian sungai, hal ini dilakukan agar memudahkan akses untuk melakukan aktivitas di sungai. Rumah-rumah masyarakat dibangun dengan menyesuaikan dan beradaptasi dengan lingkungannya. Penggunaan jenis struktur, konstruksi dan material pembentuk rumah menjadi pertimbangan dalam membangun rumah. Metode yang dipakai untuk melihat pengaruh lingkungan terhadap bentukan rumah pada permukiman tepian sungai ini memakai metode deskriptif kualitatif. Hasil dari penelitian ini didapati bahwa, konstruksi kayu dengan material alam, serta struktur pondasi panggung atau terapung menjadi pilihan pada rumah tepian sungai untuk merespon lingkungannya. Selain itu terdapat pula elemen penunjang pada rumah, seperti titian, batang, dermaga dan jamban yang menjadi akses penghubung penghuni untuk berinteraksi dengan lingkungan sungai.
\end{abstract}

Kata kunci: Rumah Tepian Sungai, Lingkungan Sungai, Kota Banjarmasin

ABSTRACT. Banjarmasin is the city that has been influenced by the environment of the river. The existence of the river plays a role to establish the identity of Banjarmasin that can be seen from the riverside settlements. One of the places which still have the local-wisdom element and dominant river cultures is Bromo Island Delta. The environment of the river is very influential in the lives and activities of the community in the settlement. The activities at the riverside make the community tend to build a residence on it, and this is done to facilitate access to have an activity on the riverside. The community houses built by adjusting and adapting to its environment. The use of structures, constructions, and material forming of the house is considered in creating them. The method that used to see the influence of the environment to the house in the riverside settlement was a qualitative descriptive method. The result of this research found that the wood construction with natural materials and the structure of the foundation stage or floated are the choice of the river house as a community respond to its environment. Besides, there are also supporting elements at home, such as terrace, logs, piers, and toilet which are being accessed connecting residents to interact with the environment of the river.

Keywords: Riverside Settlement House, River Environment, Banjarmasin

\section{PENDAHULUAN}

Kota Banjarmasin merupakan kota yang hampir sekitar $40 \%$ wilayahnya dipengaruhi oleh lingkungan sungai yang tersebar diseluruh kota. Kondisi geografis Kota Banjarmasin yang terdiri dari banyak sungai ini secara tidak langsung akan berpengaruh pada pembentukan karakter kota yang dapat dilihat dari bentuk arsitektur dan budaya sungai yang masih bisa ditemukan sampai sekarang.

Sejak dahulu sungai sangat berperan penting terhadap kehidupan masyarakat Kota Banjarmasin. Kondisi inilah yang berdampak bagi prilaku dan kehidupan masyarakat Kota Banjarmasin. Selain sebagai sumber air, masyarakat menjadikan sungai sebagai orientasi hidup dikarenakan kegiatan keseharian masyarakat tidak lepas dari peran sungai sebagai wadahnya aktivitasnya. Banyak aktivitas dan interaksi sosial yang dilakukan masyarakat di sungai, seperti berdagang, sebagai jalur transportasi, mandi, mencuci, menangkap ikan, bermain dan berkumpul yang menjadi kegiatan sehari-hari masyarakat di tepian sungai.

Lingkungan sungai merupakan pusat pertumbuhan, jalur pergerakan dan prasarana 
transportasi utama sampai sekarang. Kegiatan dan kehidupan berorientasi ke sungai sehingga hal ini dapat disebut sebagai budaya sungai. Permukiman tepian sungai merupakan salah satu hasil dari budaya masyarakat Kota Banjarmasin, kebutuhan masyarakat akan sungai sangat mempengaruhi cara berhuninya. Aktivitas masyarakat yang banyak dilakukan disungai membuat masyarakat cenderung membangun hunian atau tempat tinggalnya di tepian sungai, hal ini dilakukan agar memudahkan akses untuk melakukan aktivitas disungai.

Salah satu permukiman tepian sungai dengan budaya sungai yang masih kuat di sepanjang Sungai Martapura Kota Banjarmasin yaitu pada permukiman "Delta Pulau Bromo" (DPB). Pulau Bromo merupakan sebuah delta yang terletak di Kelurahan Mantuil, Kecamatan Banjarmasin Selatan, Kota Banjarmasin. Delta ini berada di pinggiran kota dan jauh dari pusat kota yaitu berada pada perbatasan antara Sungai Martapura dan Sungai Barito, akses pencapaian untuk menuju ke DPB hanya bisa menggunakan alat transportasi sungai. Kenyataan ini membuat lokasi objek ini terlihat unik dan menarik untuk dikaji. Permukiman pada DPB ini masih terlihat asli dan masih mencerminkan permukiman asli Kota Banjarmasin, seperti masih terdapatnya rumah lanting (rumah terapung) dan rumah-rumah pangung yang didominasi dengan material lokal. Masih minimnya pembangunan dari pemerinah menjadikan unsur kelokalan dan budaya sungai pada kawasan ini masih kuat, masyarakat di kawasan ini masih memiliki ketergantungan yang tinggi terhadap sungai.

Penelitian terdahulu pada permukiman tepian sungai lebih cenderung membahas tentang kawasan tepian sungai pada kawasan pusat kota dan area Kota Banjarmasin, sedangkan penelitian yang berada pada kawasan pinggiran kota belum terpetakan secara akademis, sehingga penelitian ini akan mengisi celah kosong pada kawasan pingiran kota dan memperkaya temuan dalam lingkup penelitian permukiman sungai di Kota Banjarmasin.

Lingkungan alam berupa sungai yang menjadi wadah sebagai tempat tinggal bagi masyarakat, yang secara tidak langsung sangat mempengaruhi masyarakat dalam membangun huniannya. Tujuan dari penelitian ini adalah untuk melihat pengaruh dari lingkungan terhadap bentukan dari rumah yang dibangun masyarakat pada permukiman tepian sungai DPB.

\section{METODE PENELITIAN}

Metode penelitian yang digunakan dalam penelitian ini yaitu menggunakan metode penelitian deskriptif kualitatif. Metode penelitian dengan deskriptif kualitatif ini dipilih dikarenakan untuk mengamati fenomena yang terjadi di lapangan, yaitu bentukan rumah di permukiman tepian sungai DPB yang dipengaruhi oleh lingkungan sungai. Pengamatan dilakukan secara empirik dalam kawasan permukiman dan sekaligus melihat dari sisi pengalaman masyarakatnya.

Lingkup kawasan penelitian hanya mengambil pada rumah-rumah yang berada pada muara Sungai Martapura yang ada di DPB, yaitu RT 06 dan RT 07. Pertimbangan pemilihan lokasi objek studi ini dikarenakan masih terdapat rumah tepian sungai yang berada di atas air (rumah lanting) yang merupakan hasil dari budaya sungai masyarakat Banjar, sehingga terdapat keragaman jenis rumah dan pengaruh budaya sungai yang tersisa pada area objek studi ini.

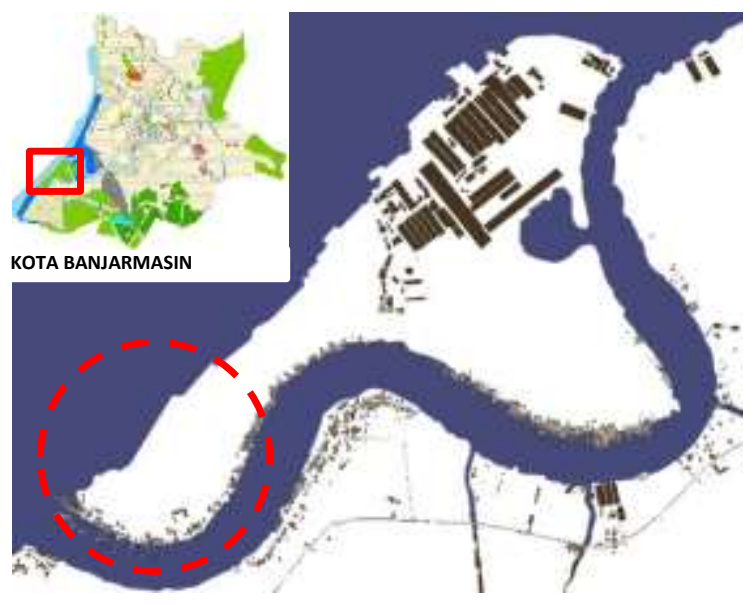

Gambar 1. Lokasi Penelitian

(Sumber: RTRW Kota Banjarmasin 2011-2031)

Teknik pemilihan sampel yang dipakai pada penelitian ini yaitu menggunakan purposive sampling. Jumlah sample rumah yang diamati yaitu 25 rumah, terdiri dari 4 rumah yang berada di atas sungai, 11 rumah yang berada di bantaran sungai dan 10 rumah yang berada di tepi sungai, dengan responden merupakan penghuni rumah yang terpilih menjadi sample objek penelitian pada rumah tepian sungai DPB.

Pengambilan data dilakukan dengan cara observasi secara menyeluruh kemasingmasing objek penelitian, wawancara dilakukan terhadap setiap pemilik rumah yang dijadikan sampel untuk melihat faktor apa saja yang 
mempengaruhi karakteristik rumah di tepian sungai DPB. Selain itu wawancara juga dilakukan pada key person, yaitu tetua kampung akan dilakukan terlebih dahulu sebagai pengetahuan awal sebelum melakukan observasi untuk mempermudah pencarian data.

\section{KARAKTERISTIK KAWASAN TEPIAN SUNGAI}

Pada hakekatnya sungai merupakan salah satu sumber air bagi kehidupan bagi manusia maupun makhluk hidup lainnya untuk bertahan hidup. Sungai menjadi lingkungan alam yang berpengaruh terhadap karakteristik Kota Banjarmasin. Pada awal perkembangannya, Kota Banjarmasin terbentuk dari permukimanpermukiman yang berada di kawasan tepian sungai Martapura yang selanjutnya berkembang kearah daratan. Hal inilah yang menyebabkan banyaknya permukiman yang berada pada kawasan tepian sungai.

Kawasan tepi sungai yaitu suatu kawasan yang memiliki orientasi ke sungai yang merupakan daerah pertemuan antara ekosistem daratan dan perairan atau sungai yang juga merupakan daerah pasang surut. Pola permukiman tepian sungai umumnya membentuk pola memanjang mengikuti bentuk sungainya. Kawasan tepian sungai memiliki beberapa kelebihan terkait fungsi dan kemudahan dalam pencapaian. Pemanfaatan lingkungan sungai dapat memudahkan manusia dalam berpindah tempat untuk mendapatkan permukiman baru, selanjutnya menetap dan berkembang, sehingga berubah menjadi permukiman yang lebih ramai, menjadi desa, lalu berkembang menjadi kota.

Terbentuknya konsentrasi penduduk pada permukiman tepian sungai dengan pola permukiman yang berjejer mengikuti disepanjang sungai, memiliki faktor utama yaitu sungai [1]. Bagi penduduk yang bermukim di kawasan tepian sungai, sungai diharapkan mampu memenuhi kebutuhan dan mempertahankan hidup mereka.

Menurut Syarif dalam memenuhi kehidupannya masyarakat kawasan sungai mampu menyesuaikan dengan lingkungan alamnya, sehingga aktivitas dan sumber mata pencaharian masyarakat sangat tergantung dari keadaan alam yaitu sungai, baik secara langsung maupun tidak langsung [2].

\section{Masyarakat Tepian Sungai}

Pola kehidupan masyarakat tepian sungai terlihat sangat sederhana, dengan cara pemanfaatan dan pengoptimalan pada ruang [3]. Kesederhanaan tersebut dapat dipengaruhi oleh tingkat pendapatan dari masyarakat di permukiman tepian sungai, sehingga berdampak pada keterbatasan dalam hal pembangunan hunian, sehingga bangunan cenderung memiliki kualitas yang rendah, faktor inilah yang menjadi salah satu penyebab kesederhanaan bentukan rumah pada masyarakat tepian sugai.

Dalam mendirikan, membangun atau menempati rumah masing-masing individu memiliki tuntutan maupun tujuan dalam memilih rumah tersebut begitu juga masyarakat yang berada di tepian sungai. Menurut Maslow, tuntutan terhadap rumah terjadi akibat intensitas kebutuhan dasar manusia yang meliputi kebutuhan fisiologis, kebutuhan akan rasa aman, kebutuhan akan hubungan sosial, kebutuhan penghargaan atas diri sendiri dan aktualisasi diri [4]. Dalam hal pemenuhan kebutuhan terhadap hunian, setiap individu selalu memiliki tuntutan maupun pertimbangan dalam pemilihan lokasi rumah, begitu juga masyarakat yang berada di tepian sungai.

\section{Kebudayaan Sungai Kota Banjarmasin}

Timbulnya kebudayaan sungai pada suku Banjar (Kota Banjarmasin) dikarenakan oleh beberapa faktor, yaitu pengaruh perkembangan geomorfologi Kalimantan Selatan, pengaruh ekosistem yang dibentuk oleh alamnya (sosial, ekonomi, politik), pengaruh kontak-kontak kebudayaan antara letak geografi Banjar, amalgamasi antar sukusuku asal dan pendatang sebagai evolusi historis, agama Islam sebagai faktor politik dan religi yang bersifat menyatukan dan memisahkan [5].

Ketergantungan masyarakat terhadap sungai membentuk kebudayaan sungai yang melekat erat dalam kehidupan bermasyarakat. Dilihat dari aspek non fisik, masyarakat kota Banjarmasin sejak dahulu dikenal sangat dekat dengan sungai. Menurut Rahman, kebudayaan sungai ini tergambar dalam kegiatan sehari hari, diantaranya adalah aktivitas ekonomi, interaksi sosial antar masyarakat, MCK, dan sebagai jalur transportasi [6]. Dilihat dari aspek fisik, budaya sungai di Banjarmasin tercermin dari bentukan arsitektur tepian sungainya. Kondisi lingkungan fisik alam sekitar sungai yang berawa menyebabkan permasalahan tersendiri bagi masyarakat Banjar yang ingin 
membangun permukiman di tepian sungai. Menghadapi kondisi lahan demikian, maka masyarakat Banjar berusaha menciptakan budaya membangun yang bersumber dari pengetahuan lokal, yaitu dengan memanfaatkan bahan-bahan lokal untuk mengatasi masalah dari lingkungan yang dipengaruhi air.

\section{HASIL DAN PEMBAHASAN}

Permukiman DPB merupakan permukiman yang berada yang berada pada sebuah delta yang di kelilingi oleh sungai dan rumah-rumah penduduk dibangun pada area tepian sungai yang secara langsung terhubung dengan sungai. Permukiman DPB berada di lingkungan sungai yang didominasi oleh unsur alami seperti rawa, kebun dan ladang. Pola sirkulasi permukiman DPB ini berbentuk linier mengikuti bentuk Sungai Martapura dan Sungai Barito yang mengelilingi DPB. Karakteristik lingkungan binaan terfokus pada lingkungan permukiman yang terdiri dari elemen-elemen permukiman berupa rumah, sirkulasi, dan fasilitas penunjang pada permukiman. Letak permukiman yang berada di area tepian sungai ini menjadikan rumahrumah yang berada pada permukiman ini hanya dihubungkan dengan jalur sirkulasi berupa titian kayu, selain itu untuk akses menuju ke sungai, dihubungkan dengan elemen penunjang berupa batang dan dermaga. Lingkungan fisik permukiman ini dibuat untuk menunjang kehidupan masyarakat yang berada pada kawasan tepian sungai yang mengikuti dan menyesuaikan dengan kondisi alam berupa sungai yang sudah terbentuk sebelumnya.

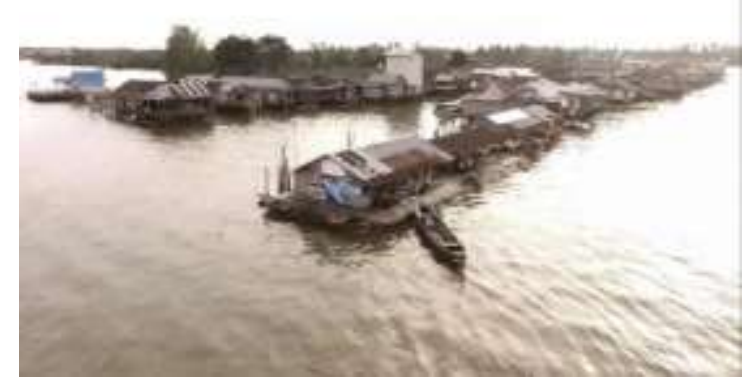

Gambar 2. Karakteritik Permukiman DPB (Sumber: Survei, 2018)

Masyarakat di permukiman DPB sebagian besar berprofesi sebagai pedagang dan petani, lokasi tempat mereka bekerja berada di DPB itu sendiri dan ada pula yang diluar DPB. Lahan yang berada di belakang rumah mereka difungsikan sebagai sawah dan ladang untuk kegiatan bertani ataupun berkebun, sedangkan untuk masyarakat dengan lokasi pekerjaan diluar permukiman DPB, mereka menggunakan sarana tansportasi jukung (perahu) pribadi, kelotok (perahu bermesin) atau feri penyeberangan untuk menyeberangi sungai dan menuju ke lokasi pekerjaannya. Belum adanya jembatan penyeberangan yang menghubungkan kawasan DPB dengan kawasan pusat Kota Banjarmasin, menjadikan alat tansportasi sungai masih sangat berperan penting dalam kehidupan masyarakat permukiman DPB. Selain itu fungsi asli dari rumah tepian sungai yaitu sebagai fungsi dagang masih dapat ditemukan di permukiman DPB. Budaya asli dari masyarakat tepian sungai yaitu berdagang di tepian sungai masih dipertahankan walaupun jumlahnya sudah mulai berkurang.

Masih bergantungnya kehidupan masyarakat DPB pada sungai inilah yang membuat budaya sungai di lokasi ini masih sangat kuat, aktivitas masyarakat yang dipengaruhi oleh lingkungan sungai ini masih terlihat asli seperti kehidupan masyarakat Kota Banjarmasin jaman dahulu. Modernisasi juga tidak merubah pandangan dan arah hidup masyarakat yang masih mengganggap sungai sebagai hal yang penting bagi kehidupannya, hal ini tercermin dari kegiatan dan aktivitas masyarakat yang masih tidak bisa lepas dari sungai, sehingga budaya sungai pada kawasan DPB ini masih terjaga.

Lingkungan sungai memiliki peran penting dalam pembentuk karakteristik pada permukiman ini yang berpengaruh terhadap bentukan rumah pada kawasan tepian sungai DPB. Berikut hasil dari penelitian yang melihat beberapa pengaruh lingkungan terhadap bentukan rumahnya di permukiman tepian sungai DPB dapat dilihat dari aspek fisik bentukan bangunannya dan aspek hubungan aktifitas sosial masyarakat dengan lingkungan sungai yang mempengaruhi bentuk bangunannya:

\section{Pengaruh Lingkungan Terhadap Bentuk Bangunan}

Kondisi permukiman yang berada di kawasan tepian sungai sangat berpengaruh terhadap tempat tinggal atau rumah bagi para masyarakat yang bermukim di permukiman ini. Rumah dibangun dengan mempertimbangkan dari aspek lingkungan sungai yang mendominasi permukiman ini, sehingga bentuk rumah seperti pada struktur konstruksi dan penggunaan material bangunan menjadi aspek 
dari rumah yang terpengaruh oleh kondisi lingkungan sungai.

\section{a. Struktur Konstruksi}

Respon masyarakat terhadap lingkungan sungai yang paling utama pada bangunan adalah dari pemilihan struktur konstruksi dan material pada rumah yang menyesuaikan dengan lingkungannya. Daya dukung tanah yang rendah yang terpengaruh pasang surut air sungai, dapat diantisipasi dengan baik oleh masyarakat setempat. Rumah-rumah pada permukiman ini memiliki struktur bangunan dengan material bangunan yang dapat beradaptasi dengan lingkungannya.

Struktur pada bagian atap dan dinding yang digunakan pada rumah-rumah di permukiman ini menggunakan struktur rangka kayu. Penggunaan model atap pada rumah di permukiman ini didominasi oleh penggunaan model atap pelana, pemilihan model atap ini dikarenakan atap pelana merupakan model atap yang sederhana, sehingga tidak memberikan beban pada pondasi rumah. Sedangkan untuk pondasi, jenis pondasi panggung dan pondasi terapung menjadi pilihan bagi masyarakat dalam membangun rumah. Penggunaan sistem pondasi ini dimaksudkan untuk merespon dan beradaptasi dengan lingkungan sungainya.

Pondasi terapung biasanya digunakan pada rumah yang berada di atas sungai atau disebut sebagai rumah lanting. Rumah lanting merupakan rumah dengan fungsi dagang untuk mempermudah kegiatan jual beli di area sungai. Dikarenakan posisinya yang berada di atas sungai dan lebih menjorok ke tengah sungai, sehingga dibutuhkan jenis pondasi yang dapat menyesuaikan dengan kondisinya.

Pondasi dengan jenis terapung dipilih sebagai solusi dari kebutuhan fungsi dan posisi yang didasari oleh pengaruh lingkungan sekitar. Pondasi terapung berfungsi sebagai penumpu beban dan juga sebagai alat pengapung untuk rumah lanting. Karena rumah ini dibangun di atas air maka diperlukan alat pengapung berupa bambu/paring. Penggunaan pondasi terapung ini sangat respon terhadap lingkungan sungai, dikarenakan tidak menghambat atau menghalangi arus sungai, bahkan penggunaan rumah model terapung ini juga dapat mengurangi erosi atau pengikisan tanah yang diakibatkan oleh arus sungai.

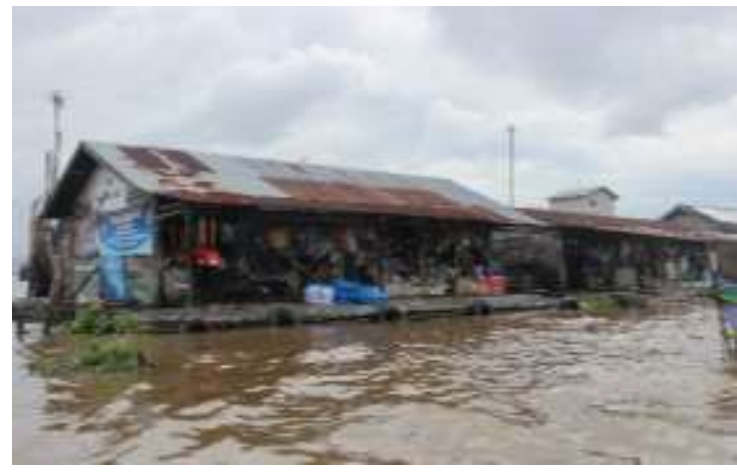

Gambar 3. Rumah dengan Pondasi Terapung (Sumber: Survei, 2018)

Selain sistem pondasi terapung, terapat pula sistem pondasi yang digunakan oleh rumah pada permukiman ini dengan tipe panggung. Rumah -rumah yang memakai pondasi ini berada pada area tepi dan bantaran sungai dengan fungsi sebagai hunian dan ada pula yang berfungsi sebagai rumah dagang. Rumah panggung umumnya berada pada area transisi antara daratan dan sungai, maka kondisi tanah di kawasan ini berupa tanah rawa yang berlumpur dan berair, sehingga pemakaian pondasi harus diperhitungkan dalam membangun rumah bantaran sungai ini. Pemakaian pondasi panggung ini memakai material tongkat ulin dengan panjang bervariasi antara 1-2,5 $\mathrm{m}^{2}$, sehingga terdapat jarak antara bagian lantai rumah dengan sungai. Penyesuaian tinggi ini dilihat dari kondisi pasang tertinggi air sungai, sehingga dapat memperhitungkan tinggi rumah yang di bangun. Pada bagian bawah tongkat ulin terdapat pancangan kayu galam yang berfungsi sebagai pengikat lumpur sehingga tiang ulin tidak terus masuk ke dalam tanah lumpur. Penggunaan pondasi panggung ini dimaksudkan agar tidak menghambat aliran sungai, selain itu terdapatnya jarak antara sungai dengan bangunan merupakan salah satu cara untuk mendapatkan kenyamanan pada area dalam rumah pada siang hari, dikarenakan angin dapat melalui area bawah kolong rumah dan masuk pada celah-celah papan lantai pada rumah yang memberikan kenyamanan pada area dalam rumah.

Penggunaan struktur panggung dan material kayu pada bangunan di kawasan DPB ini selain untuk menyesuaikan dengan kondisi alam yang didominasi oleh sungai dan juga tanah rawa, juga dimaksudkan untuk penghawaan alami pada rumah. Kondisi iklim pada Kota Banjarmasin bersifat tropis, yang mengakibatkan cuaca pada kawasan ini cenderung panas pada siang hari dan dingin pada malam hari. Penggunaan konstruksi 
panggung dan susunan papan kayu ulin pada lantai dan dinding dimaksudkan agar angin dapat masuk ke dalam rumah dari celah dinding dan lantai bangunan sehingga dapat mengurangi hawa panas pada siang hari dan kondisi dalam bangunan terasa sejuk.

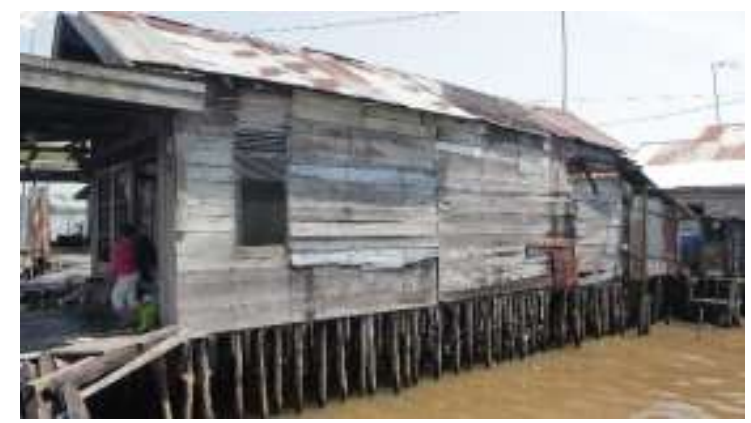

Gambar 4. Rumah dengan Pondasi Terapung (Sumber: Survei, 2018)

Penggunaan struktur konstruksi terapung dan panggung dengan menggunakan bahan bangunan lokal seperti kayu ulin, galam dan bambu telah menunjukkan adaptasi yang baik dan sesuai dengan alamnya. Selain itu kesesuaian ini juga dapat menciptakan keseimbangan ekologi ditepian sungai karena adanya hubungan timbal balik antara manusia alam dan hunian/arsitektur.

\section{b. Material Bangunan}

Material atau bahan-bahan bangunan yang dipakai pada rumah-rumah di permukiman DPB secara umum masih didominasi dengan pemakaian material alam, walaupun beberapa bangunan pada permukiman DPB sudah ada yang menggunakan jenis konstruksi dan bahan penutup bangunan yang modern. Material tersebut berupa kayu yang umumnya pada daerah Kalimantan masih mudah untuk didapatkan. Jenis kayu yang dipakai menggunakan kayu dengan jenis kayu ulin, kayu galam, batang kayu gelondongan, bambu dan jenis kayu lain yang tersedia di lingkungan sekitar.

Penggunaan material kayu ini digunakan di hampir keseluruhan bagian rumah, mulai dari struktur rangka atap, badan bangunan, pondasi dan pada bagian penutup bangunan seperti penutup atap, lantai dan dinding bangunan. Struktur konstruksi pada bangunan secara umum menggunakan material dengan jenis kayu ulin, baik dari rangka atap dan rangka badan rumah. Untuk rumah dengan jenis panggung pada bagian pondasi menggunakan kayu dengan jenis ulin. Pemilihan material kayu ulin sebagai pondasi dikarenakan jenis kayu ini akan bertambah kuat jika terkena air. Selain itu pada pondasi terdapat pula material dari kayu dengan jenis galam, kayu galam bersifat mengikat lumpur sehingga dapat digunakan sebagai pondasi pada tanah rawa.

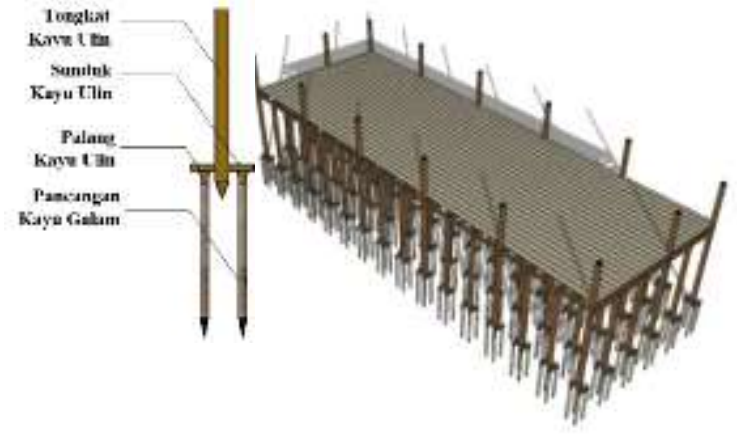

Gambar 5. Material Pondasi Panggung (Sumber: Survei, 2018)

Untuk rumah dengan pondasi terapung atau rumah lanting memiliki perbedaan pada jenis material pondasinya. Pada awalnya jenis material terapung pada rumah dengan tipe rumah terapung menggunakan batang kayu gelondongan sebagai pengapung rumah, penggunaan material pengapung memakai kayu gelondongan dikarenakan pada jaman dahulu jenis material ini masih mudah untuk didapatkan, tetapi pada masa sekarang kayu gelondongan sudah jarang ditemukan sehingga dibutuhkan material untuk menggantikan kayu gelondongan. Bambu merupakan material yang menjadi alternatif pengganti kayu gelondongan sebagi material pondasi pengapung rumah, dikarenakan jenis material ini masih mudah untuk didapatkan pada saat ini di Kota Banjarmasin. Untuk mengapungkan rumah diperlukan kurang lebih 100 batang paring/bambu yang diikat menjadi 3 sampai 4 bagian, dengan panjang masingmasing paring berkisar kurang lebih $10 \mathrm{~m}$. Pada beberapa kasus rumah lanting yang berada di pusat Kota Banjarmasin, terdapat beberapa rumah lanting yang menggunakan drum air sebagai material pengapung. 


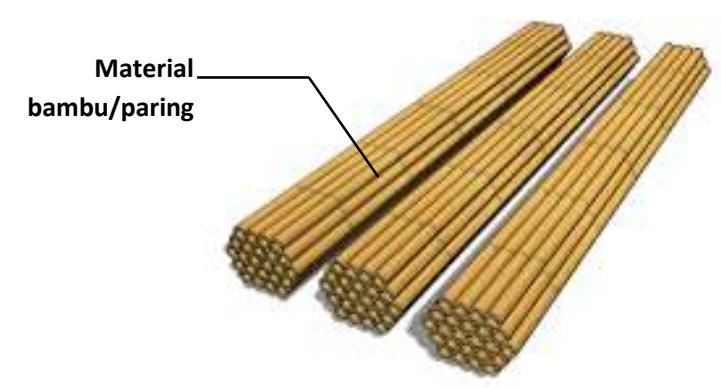

Gambar 6. Material Bambu Sebagai Pengapung (Sumber: Survei, 2018)

Penggunaan penutup rumah, baik untuk penutup atap, dinding dan lantai juga masih memakai material dengan beberapa jenis kayu. Pada penutup dinding menggunakan jenis kayu lain seperti papan kayu lanan atau meranti yang bersifat ringan agar tidak memberi beban terhadap pondasi. Untuk material penutup lantai semua rumah yang ada di permukiman ini menggunakan material kayu ulin sebagai bahan penutup lantai yang dikenal kuat. Sedangkan pada penutup atap rumah di permukiman ini didominasi oleh pemakaian material dengan jenis atap sirap, tetapi terdapat pula material lainnya seperti penggunaan material penutup atap dari bahan bangunan terbaru, seperti seng dan genteng metal.

\section{Pengaruh Lingkungan Terhadap Aktifitas Sosial Masyarakat}

Lingkungan pada dasarnya merupakan tempat yang dijadikan media untuk bersosialisasi antar warga. Jika melihat pada lingkungan sungai pada permukiman DPB, pada kawasan ini sungai masih memainkan peranan penting dalam interaksi antar warga masyarakatnya. Banyak kegiatan yang dilakukan di area sungai. Dari aktivitas dan kegiatan masyarakat inilah yang pada nantinya akan menciptakan elemen-elemen fisik yang dapat mendukung kegiatan masyarakat.

Aktivitas warga, yang tinggal di permukiman ini dimulai sejak pagi hari. Aktivitas yang dilakukan antara lain yaitu mandi dan mencuci, atau memulai aktivitas ekonomi. Banyak warga masyarakat, yang mandi dan mencuci di sungai dan saling bercengkrama antar warga. Kegiatan ini dikaukan pada elemen penunjang berupa batang, jamban atau diatas titian. Walaupun pada permukiman ini air PDAM sudah masuk, tetapi untuk aktivitas mandi dan mencuci masyarakat masih banyak yang menggunakan sungai, ini dikarenakan kebiasaan masyarakat yang masih tidak bisa lepas dan masih terpengaruh dengan keberadaan sungai. Dengan aktivitas yang dilakukan bersama di sungai, maka mereka bisa berinteraksi dengan para tetangga yang sama-sama sedang mandi di sungai.

Siang hari aktivitas di kawasan sungai mulai berkurang, selain pedagang dan aktivitas transportasi yang lalu lalang di area sungai. Para laki-laki bekerja, sedangkan untuk ibu rumah tangga melakukan pekerjaan rumah dan ada juga beberapa yang berkumpul dan berbincang bincang di area salah satu penghuni rumah, seperti di atas titian atau di teras rumah. Ketika sore hari aktivitas di permukiman ini kembali ramai, anak-anak yang sudah pulang sekolah banyak yang berkumpul dan bermain di area sungai, mereka bermain di titian kayu dan batang untuk berenang di sungai. Bapak-bapak banyak yang memancing di sungai untuk mengisi waktu luang sambil berbincang bincang, para ibu-ibu juga berkumpul dan berbincang di area titian atau batang sambil menjaga anaknya bermain.

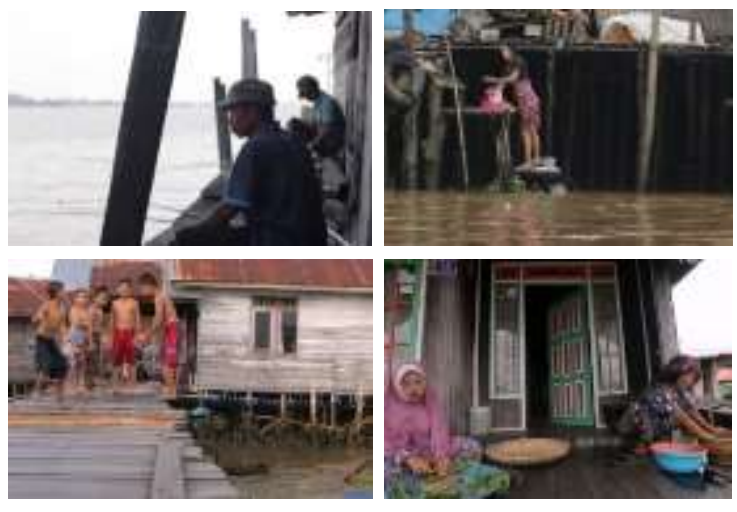

Gambar 7. Aktivitas Masyarakat Permukiman DPB (Sumber: Survei, 2018)

Aktivitas atau kegiatan masyarakat juga sangat dipengaruhi oleh lingkungannya, belum adanya akses jalan darat membuat masyarakat sangat bergantung pada sungai di semua aktivitasnya. Untuk mewadai aktivitas masyarakat ini maka muncul elemen penunjang yang terdapat pada masing-masing rumah untuk tempat masyarakat beraktivitas. Elemen penunjang merupakan bentuk respon terhadap lingkungan dan sebagai wadah penghubung bagi penghuni rumah dengan lingkungannya. Terdapat 4 jenis elemen penunjang yang ditemukan pada rumah-rumah di permukiman DPB, yaitu:

1. Titian merupakan sebuah jalur sirkulasi yang dipakai pada permukiman tepian sungai. Selain untuk jalur sirkulasi, titian berfungsi sebagai akses pencapaian penghuni menuju rumah-rumah, menuju sungai, ataupun sebagai jalur interaksi 
masyarakat di dalam permukiman. Titian memiliki konstruksi sederhana, dengan menggunakan konstruksi kayu ulin dan lantai juga terdiri dari susunan papan dengan jenis kayu ulin. Posisi titian pada rumah biasanya berada pada depan atau samping rumah.

2. Batang merupakan wadah transisi untung penghuni rumah yang menghubungkan antara area rumah dengan area sungai, bentuk batang seperti tangga yang umumnya memakai sistem panggung dan menyatu pada pondasi rumah bagian depan. Banyak kegiatan yang dapat dilakukan penghuni di batang, misalnya sebagai tempat mencuci baju, sebagai tempat memancing, sebagai tempat naik turunnya penghuni dari area sungai ke area rumah atau sebagai tempat menambatkan perahu. Batang terletak pada area depan rumah atau pada bagian belakang rumah.

3. Dermaga merupakan sebuah wadah yang berfungsi sebagai tempat naik turun penumpang atau tempat bongkar muat dan tempat bertambat bagi alat transportasi sungai, seperti jukung, kelotok atau speed boat. Dermaga pada rumah di permukiman ini menggunakan jenis terapung dengan material pengapung drum dan lantai ulin. Dermaga diikatkan pada pancangan kayu galam yang berada didepan bangunan agar tidak hanyut terbawa arus atau berpindah tempat. Biasanya dermaga terhubung secara langsung dengan batang yang berada di depan rumah.

4. Jamban merupakan elemen penunjang dengan yang bersifat umum dan berfungsi hanya sebagai tempat buang air saja. Jamban pada rumah di permukiman ini memiliki struktur panggung dengan konstruksi kayu ulin. Jamban biasanya berada pada area samping rumah.
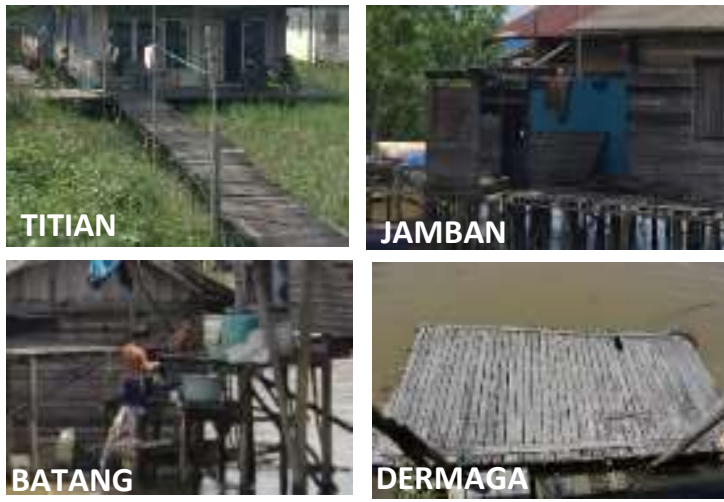

Gambar 8. Elemen Penunjang pada Rumah (Sumber: Survei, 2018)
Terdapatnya elemen penunjang pada permukiman atau pada rumah yang berada di kawasan tepian sungai menjadikan ciri khas tersendiri pada karakteristik rumah di permukiman tepian sungai DPB. Munculnya elemen penunjang ini dimaksudkan untuk memfasilitasi kegiatan atau aktivitas peghuni rumah dengan lingkungannya yaitu sungai.

\section{KESIMPULAN}

Karakteristik antara lingkungan alami dan binaan pada permukiman DPB menjadi satu kesatuan, lingkungan binaan tumbuh dan berkembang dengan menyesuaikan dengan lingkungan alamnya, yaitu sungai. Terbentuknya rumah masyarakat pada permukiman tepian sungai di DPB menunjukkan bahwa masyarakat dapat hidup dan menyesuaikan diri dengan lingkungan yang didominasi oleh sungai. Pengaruh lingkungan dalam kehidupan masyarakat di lingkungan sungai ini dapat dilihat dari bentukan rumah dengan penggunaan struktur konstruksi dan material rumah, seperti pemakaian jenis pondasi panggung atau terapung dan penggunaan material alam seperti kayu ulin, galam dan bambu yang menyesuaikan dengan lingkungannya. Selain itu pada rumah juga terdapat elemen penunjang seperti titian, batang, dermaga dan jamban yang merupakan hasil dari pemenuhan kebutuhan atau aktivitas masyarakat dalam menghadirkan wadah penghubung dengan lingkungan sungai.

Arsitektur tepian sungai Kota Banjarmasin merupakan salah satu wujud dari budaya sungai masyarakat Banjarmasin. Peran lingkungan sungai sangat berpengaruh terhadap aktivitas keseharian masyarakat dan cara membangun rumahnya. Hal ini dilakukan untuk dapat menyesuaikan terhadap pengaruh lingkungan sungainya yang menjadi tempat bermukim. Pola perilaku pada diri individu atau masyarakat dalam menjalankann aktivitas kehidupan sehari-hari dengan beradaptasi terhadap lingkungan sungai, membentuk sebuah karakteristik yang menjadikan pembeda dengan masyarakat di permukiman lain. Sehingga menjadikan ciri khas lokalitas tersendiri bagi permukiman yang berada di kawasan tepian sungai.

\section{DAFTAR PUSTAKA}

[1] Mentayani, I. (2016). Identitas dan Eksistensi Permukiman Tepi Sungai di Banjarmasin. Potensi, Peluang, dan Tantangan Pengelolaan Lingkungan Lahan Basah secara Berkelanjutan: 1-6. 
Banjarmasin: Universitas Lambung Mangkurat.

[2] Syarif, E. \& Nurmaida, A. (2016). Arsitektur Hijau pada Morfologi Permukiman Tepi Sungai Tallo. Prosiding Temu IImiah IPLBI. Malang: Institut Teknologi Nasional.

[3] Mentayani, I. dan Prayitno, B. (2011). Arsitektur Tepian Sungai: Potret Life Style Masyarakat di Kota Banjarmasin. Seminar Nasional Dan Workshop Life Style and Architecture Yogyakarta: Universitas Atmajaya.

[4] Maslow, A., H. (2010). Motivation and Personality. Jakarta: Rajawali.

[5] Mentayani, I. (2009). Pudarnya Makna Kebudayaan Sungai di Kota Banjarmasin.

[6] Rahman, M. A. U. (2014). Pelestarian Rumah Lanting Berlandaskan Budaya Sungai Masyarakat Kota Banjarmasin. EJournal Graduate Unpar. 1 (2): 221-231.

[7] Pemerintah Kota Banjarmasin. (2011). Rencana Tata Ruang Wilayah (RTRW) Kota Banjarmasin Tahun 2011-2031. 
